Janina FRAS

Uniwersytet Wrocławski

\title{
O pojmowaniu infotainmentu i nadmiernej rozrywkowości mediów masowych we współczesnym medioznawstwie
}

\begin{abstract}
7 apożyczony z angielszczyzny termin infotainment, używany mniej więcej od dekady głównie przez publicystów i badaczy mediów, jest najczęściej niedefiniowany. Ten specjalistyczny anglicyzm i słowo modne zapewne zasili trwale polszczyznę ogólną w odmianie naukowej ${ }^{1}$, choć z pewnością nie wejdzie do dyskursu potocznego. Warto zastanowić się nad jego szerokim zakresem znaczeniowym i rozwarstwieniem semantycznym - także po to, by przeciwstawić się niektórym użyciom.

Infotainment, jako określenie zdominowanej przez rozrywkowe widowiska zawartości współczesnych mediów masowych (dalej: MM), a głównie najpopularniejszego $\mathrm{z}$ nich - telewizji, pojawiło się $\mathrm{w}$ angielszczyźnie amerykańskiej z końcem lat 70. XX w., najpierw w kręgu krytycznych obserwatorów rozwiniętych zachodnich rynków medialnych. W druku po raz pierwszy miał się nim posłużyć Ron Eisenberg w periodyku „Phone Call” na początku 1980 r. $^{2}$ Termin został szybko
\end{abstract}

Słowo potwierdzone w wielu kontekstach w Narodowym Korpusie Języka Polskiego www.nkjp.pl; wyszukiwarka PELCRA na tejże stronie umożliwia określenie profilu czasowego słowa (wzrost częstości użycia rozpoczął się w 2007 r.) i profilu występowania (słowo występuje głównie w tekstach publicystycznych, w prasie opinii); zob. http://www.nkjp.uni.lodz.pl/index_adv.jsp?query=infotainment\&Submit (1.07.2012). Drukowane słowniki wyrazów obcych nie zawierają słowa (zob. M. Bańko, Wielki słownik wyrazów obcych, Wydawnictwo Naukowe PWN, Warszawa 2010). W Słowniku terminologii medialnej z 2006 r. przyjęto szeroką definicję infotainmentu: ,wypowiedź medialna łącząca w sobie informacje i rozrywkę” (Słownik terminologii medialnej, red. W. Pisarek, Universitas, Kraków 2006, s. 82), a za typowe gatunki infotainment uznano: ,talk show, reality show, teleturnieje typu »Milionerzy«".

2 Za: T. Jagodziński, Przekleństwo inforozrywki, „Znak” 2002, nr 2 (251), s. 5-12. Warto zauważyć, że terminu nie użył N. Postman w I wydaniu Amusing Ourself to Death: Public Discourse in the Age of Show Business, Viking, New York 1985. 
zapożyczony do wszystkich głównych języków europejskich - niemieckiego, francuskiego, hiszpańskiego, włoskiego, nie dziw więc, że z końcem XX w. pojawił się także w polskich publikacjach naukowych, gdzie wraz z kilkoma innymi zapożyczonymi neologizmami, używanymi $\mathrm{w}$ tekstach naukowych - politainment, politicotainment, edutainment, tworzy już nawet pewną serię terminologiczną.

Zachodnim badaczom zawartości mediów nieobca jest już krytyczna refleksja pragmalingwistyczna nad tym terminem: „Inforozrywka jest głównie modnym słowem-wytrychem, choć termin tabloidyzacja wydaje się być już wystarczający"3.

W świecie mediów zachodnich lat 80. i 90. XX w., zdominowanych przez popularna, komercyjną telewizję, infotainment zyskał dwie główne interpretacje:

- (-) w kręgach dziennikarskich i badaczy mediów (szkoła krytyczna, krytyczna analiza dyskursu, dalej: KAD) stał się synonimem spłycania i powierzchownego traktowania wiadomości (głównie w serwisach informacyjnych), pogoni za tanią sensacją, wreszcie - degradacji zawodu dziennikarskiego i komercjalizacji MM;

- $(0,+)$ w podejściu zarządzających mediami menedżerów - pozytywne słowo-wytrych, otwierające drogę do komercyjnego sukcesu (dzięki tej formule wzrasta oglądalność, klikalność, etc.).

Jak zaznaczono w nawiasie powyżej, w refleksji naukowej słowu towarzyszy głównie konotacja negatywna - krytycy współczesnych MM oraz procesów i zjawisk: medializacji, tabloidyzacji, mediokracji, berluskonizacji, używają tego terminu, piętnując rozliczne negatywne następstwa $^{4}$ zdominowania przez treści i przekazy rozrywkowe zawartości głównie telewizji, ale także tabloidowej prasy i sieci.

${ }^{3}$ C. Holtz-Bacha, Political communication research abroad Europe, w: Handbook of Political Communication Research, red. L. L. Kaid, Lawrence Erlbaum Associates, Mahwall 2004, s. 467.

4 Autorzy tych tekstów anonsują już w tytułach swój negatywny osąd ekspansji rozrywki, od mocnego Postmanowskiego - Zabawimy się na śmierć czy sugestywnego: S. Brenton, R. Cohen, Polowanie na ludzi, Wydawnictwo Literackie MUZA S.A., Warszawa 2004. Por. także tytuły publikacji polskich: T. Jagodziński, Przekleństwo inforozrywki, „Znak” 2002, nr 2 (251); K. Żurawski, Wirus wiecznej zabawy, „Gazeta Wyborcza” z 9.02.2009; J. Żakowski, Cukierki dla mediożercy, „Polityka”, nr 2600 z 14.04.2007; W. Smoczyński, Koniec wiadomości, „Polityka”, nr 2691 z 7.02.2010. 


\section{Termin nowy, tradycja kulturowa dawna}

Oczywiście, tradycja łączenia w wypowiedziach publicznych treści stricte informacyjnych z rozrywkowymi jest tak stara jak ludzkość. Już w czasach przedpiśmiennych, powracający z polowań ubarwiali zapewne opowieści o swoich wyczynach, by zaciekawić słuchaczy. Potrzeba wrażeń i ekscytacji jest bowiem jedną z odwiecznych potrzeb społecznych, a eksponowanie sensacyjności i niezwykłości wydarzeń w relacjach o nich, celem uzyskania korzyści finansowych, jest starsze od najstarszych mediów, także tabloidowych ${ }^{5}$.

Współcześni propagatorzy stylu infotainment wdrażają więc - niestety, do przesady - znane, odwieczne zasady skuteczności komunikacyjnej i perswazyjnej: „uczyć bawiąc” czy „propagować bawiąc”. Rozrywka zawsze była skutecznym wehikułem perswazji, jednakże współcześnie powszechnie dostępne MM bardzo tę skuteczność zwielokrotniają, dając łatwe narzędzie perswaderom (komercyjnym, politycznym, religijnym etc.) i zmieniając znacząco proporcje zawartości komunikatów w publicznym obiegu na rzecz przewagi trywialnej rozrywki, kosztem treści racjonalnych i merytorycznie istotnych.

Warto też przypomnieć, że człowiek to w istocie homo ludens, a popularne media masowe jak bodaj żadne dotąd spełniają oczekiwania tej przyjemności, co już w 1695 r. dostrzegł Kaspar Stieler w książce o prasie Zeitungs Lust und Nutz, gdy pisał o dwu podstawowych przesłankach pozytywnej selekcji jej zawartości: przypuszczalna przyjemność (Lust) odbiorcy z lektury i jej użyteczność (Nutz) ${ }^{6}$.

Już w dziennikarstwie przedtelewizyjnym, czyli opartym na słowie pisanym, cenione były umiejętnosci: niezanudzania, przyciagania uwagi, pisania w sposób „lekki” i przystępny, po to, by przy okazji przedstawić i wyjaśnić zawiłe kwestie i zjednać odbiorców. Zapewne gatunkami prasowymi, które otworzyły drogę nadmiernej rozrywkowości były: felieton, fait divers i kronika towarzyska. Jednakże to z komercyjnymi mediami wizualnoaudialnymi związane są niewątpliwie: maksymalne nastawienie na zaspokojenie oczekiwań publiczności w zakresie niewybrednej rozrywki, skracanie dystansu i gotowość do pochlebstw w publicz-

${ }^{5}$ Zob. więcej: J. Hajduk-Nijakowska, Kulturowe źródła tabloidyzacji przekazów, w: Tabloidyzacja języka i kultury, red. I. Kamińska-Szmaj, T. Piekot, M. Poprawa, „Oblicza komunikacji” 2010, nr 3, Wrocław 2010, s. 9-23.

${ }^{6}$ Za: Stownik terminologii medialnej, red. W. Pisarek, op. cit. 
nych kontaktach komunikacyjnych, nadmierna wizualizacja i uproszczenie przekazów, infantylizacja i miałkość ich treści.

\section{Podstawowe przybliżenie definicyjne}

Utrwalone w angielszczyźnie znaczenie dokumentuje najnowsza internetowa edycja Oksfordzkiego Stownika Języka Angielskiego; termin jest używany na określenie: 1) materiału emitowanego przez media elektroniczne, mającego jednocześnie informować i bawić; oraz 2) prezentowania informacji w sposób rozrywkowy. Dotyczy więc zawartości MM a ściślej sposobu kształtowania i podawania komunikatów medialnych - w definicji słownikowej określonych wieloznacznym hiperonimem materiat. Infotainment stanowi zatem swoistą formułę (styl) wypowiedzi w MM, głównie wypowiedzi informacyjnych typu: serwis informacyjny i wiadomość/news/notatka, sprawozdanie czy sylwetka. Istotą tej formuły jest:

- określony dobór treści wypowiedzi - przeważają informacje niepoważne, błahe, nadmiernie/niepotrzebnie spersonalizowane, plotkarskie, skandalizujące, ekscytujące. Także w polszczyźnie upowszechnia się ang. określanie ich mianem wiadomości miękkich (ang. soft news - za: G. Tuchman ${ }^{7}$ );

- dobór systemów znakowych i formy wypowiedzi; w telewizyjnych serwisach informacyjnych, są to zwłaszcza: oprawa (bloki reklamowe; plansza początkowa dynamiczna i ,wirtualna”, takiż motyw muzyczny), wystrój i kolorystyka studia; dobór dziennikarzy i ich zachowań (dobry wygląd, skrócenie dystansu wobec publiczności - wdzięczenie się i przypodobywanie); przewaga zawartości ikonicznej newsów, indukcyjna konstrukcja tekstu newsów, stereotypowi bohaterowie; potoczna, emocjonalna narracja, takaż leksyka i gramatyka.

Kreatorzy wypowiedzi w formule infotainment uwzględniają:

- preferencje masowej publiczności (w tym akceptację potocznego pojęcia normy oraz gotowości do ekonomizowania wysiłku w sytuacji nadmiaru przekazów medialnych, a często także: lenistwa umysłowego),

- konkurencję z innymi mediami,

7 G. Tuchman, Making News. A Study in the Construction of Reality, London 1978 , s. $47-57$. 
- akceptację porządku społecznego i głównego nurtu kultury, czyli kultury popularnej.

W niektórych pracach medioznawczych i genologicznych infotainment jest uznawany także za nowy gatunek wypowiedzi, wypierający już istniejący gatunek - wiadomość dziennikarską/news. Zakłada się nawet istnienie megagatunku lub pola gatunkowego wypowiedzi telewizyjnych informacyjno-rozrywkowych - krytykę tego podejścia przeprowadzono poniżej.

\section{Infotainment jako zapożyczony neologizm}

W interpretacji analizowanego terminu kluczowe są dwie kwestie: 1) zapożyczenie z odmiennego gramatycznie języka, 2) złożoność leksemu (to tzw. hybryda słowotwórcza: info[rmation] + [enter]tainment).

Przede wszystkim warto zwrócić uwagę, że hybrydowy tryb utworzenia neologizmu nie jest zgodny z polskimi zwyczajami derywacyjny$\mathrm{mi}^{8}$ - w polszczyźnie jeśli już - choć stosunkowo rzadko - dochodzi do tworzenia złożeń wyrazowych, to z całych słów, a nie jedynie ich fragmentów. O ile coraz popularniejszy staje się w polszczyźnie zwyczaj wykorzystywania wyrazistych semantycznie części inicjalnych słów obcych (np. cząstka info- w terminach: infografia, infografika, inforadio ale informetria), to nie ma zwyczaju ucinania początku drugiego członu złożenia. W języku angielskim przyzwolenie dla tego typu dekonstrukcji łączonych słów jest większe (zob. tab. 1 poniżej).

Spolszczona wersja słowa inforozrywka (zob. także podobnie: politorozrywka, spopularyzowana w tytule książki T. Olczyka) unaocznia opisaną odmienność słowotwórczą - w polskim słowie jest, zamiast angielskiego „uciętego”, pełny człon drugi. Swoją drogą, użycie w spolszczonym terminie całego słowa rozrywka trafnie oddaje szczególną istotność tejże w opisywanym zjawisku ${ }^{9}$.

Zapożyczenie danego słowa z innego języka (dziś najczęściej z języka angielskiego) nie oznacza w istocie pełnego jego przejęcia. Każdemu słowu bowiem w podstawowym języku towarzyszy określona, swoista

8 Zob. D. Ochmann, Nowe wyrazy złożone o podstawie zdezintegrowanej w języku polskim, Księgarnia Akademicka, Kraków 2004.

9 Termin w żargonie dziennikarskim jest polszczony także jako inforywka, infozrywka; I. Krzemiński tłumaczy infotainment opisowo: informacyjna rozrywka. 
otoczka kulturowa i konteksty użycia, które w języku i kulturze adaptującej nie istnieją lub są inne. Infotainment jest świetnym przykładem na wszystkie te różnice. I tak, nasycanie rozrywką ${ }^{10}$ przekazów informacyjnych w mediach, najpierw amerykańskich, a następnie zachonioeuropejskich, to bardziej rezultat wieloletnich przemian ewolucyjnych systemu społecznego i medialnego po II wojnie światowej, w Polsce - zmian rewolucyjnych (główną cezurą jest rok 1989; choć zapewne także znaczenie dla nasilenia tego zjawiska ma powstanie kanału informacyjnego TVN24 w 2001 r., wejście „Faktu” do Polski w 2003 r., a ostatnio - błyskawiczne upowszechnienie YouTube'a). W kulturze anglosaskiej refleksja nad ważnością widowiskowości, wizualnego aspektu przekazów telewizyjnych jest dość odległa, z telewizji przecież wywodzą się najpopularniejsze wzorce takich produkcji. Już od początku lat 70. XX w. zwracano uwagę, że:

1) w telewizji istotniejsze jest to, co widać, niż to, co słychać;

2) w serwisach informacyjnych preferowane są wiadomości, zawierające składniki filmowe, także własne wypowiedzi reporterów, krótkie wywiady;

3) telewizja zawsze preferuje najświeższe wiadomości, które można przedstawić w formie filmowej na żywo ${ }^{11}$.

W Polsce głębsza refleksja naukowa nad rolą telewizji, jej widowiskowością i rozrywkowością mogła się pojawić dopiero ćwierć wieku później. Ważnym polskim kontekstem jest spektakularne odcinanie się od tradycji polskich serwisów informacyjnych z okresu PRL, serwisów niemal całkowicie wyzbytych treści rozrywkowych, których wzorem były komunikaty urzędowe, zaś oficjalność, bezosobowość i formuliczność „Dziennika telewizyjnego" maskowały lub obiektywizowały jedyną obowiązującą ideologię. Niewielu dzisiejszych telewidzów, godzących się na formułę infotainment ma świadomość, że poufałość i nadmierna ekspresja mogą pełnić taką samą rolę w przekonaniu odbiorcy do ,jedynie słusznego poglądu", jak programowa indoktrynacja w czasach totalitarnych.

Tak szybką akceptację polskiej publiczności dla zastępującej dystans i indoktrynację nadmiernej bliskości i rozrywkowości serwisów informacyjnych $^{12}$, można zatem uznać za przejaw odreagowania przeszłości.

10 Czyli: urozrywkowianie od czasownika urozrywkowić.

11 Tak np. w: J. Tunstall, Media Sociology: A reader, Constable, London 1970.

12 Zob. więcej: T. Piekot, Dyskurs polskich wiadomości prasowych, TAiWPN Universitas Kraków, Kraków 2006, s. 285. 
Współcześnie jednak sytuacja komunikacyjna i perswazyjna jest bardziej złożona i... trudniejsza niż ta przed 1989 r. Wszechobecna w ówczesnych serwisach ideologia była stosunkowo prosta i łatwa do identyfikacji (Z. Herbert ośmieszył lekceważącą oceną jej retorykę: metafory jak cepy); obecnie niezliczone serwisy informacyjne (prasowe, radiowe, telewizyjne czy w sieci), zawierają rozmaite przesłania ideologiczne - o wiele mniej jawne niż w PRL i zręczniej maskowane, właśnie przez familiarność, wdzięk prowadzących, potoczność (nie tylko językowa), przewagę dynamicznie zmontowanego materiału filmowego nad tekstem werbalnym etc.

Pełna adaptacja terminu złożonego łączy się z odniesieniem do treści obu bazowych pojęć. Trzeba zaznaczyć, że i information, i entertainment należą do pojęć abstrakcyjnych, o szerokim zakresie użycia i wymykajacej się precyzyjnemu wyznaczeniu treści. Obu, i w polskim, i w angielskim, towarzyszą spory aksjologiczne; filozoficzna kwestia istnienia poza ludzkim umysłem (obiektywnie czy jedynie subiektywnie?) dotyczy przecież nie tylko piękna i prawdy, ale także faktów i tego, co ludzi bawi.

Z pojęciem informacji łączy się mit obiektywizmu przekazów informacyjnych i dziennikarskich, na Zachodzie kultywowany w sposób ciagły, media w Polsce mogły doń powrócić po półwieczu PRL-u. Ponadto, rozważając znaczenie informacji $\mathrm{w}$ terminie infotainment warto mieć świadomość wyjściowej dwuznaczności słowa dla wielu użytkowników: 1. składnik treści wypowiedzi, 2. gatunek wypowiedzi. Ponieważ celem badawczym niniejszego tekstu jest także uściślenie terminologii komunikologii i medioznawstwa - postuluję, by jednoznacznie odnosić informację jedynie do treści komunikatów medialnych (jako przejawianie się entropii) i nie uznawać informacji za nazwę gatunku dziennikarskiego. Gatunek przekazujący treść informacyjną to zawsze wiadomość albo $\mathrm{z}$ angielska news, a nie informacja - ta stanowi składnik treści wielu gatunków wypowiedzi, między innymi wiadomości ${ }^{13}$.

Jeśli analizowany termin zostanie spolszczony i kluczowe dla analizowanego złożenia pojęcie entertainment, zostanie przełożone jako rozrywka, dochodzi do utraty ważnego składnika znaczenia, które jest oczywiste dla użytkowników angielskiego. Entertainment w angielskim znaczy bowiem: 1) zabawa, rozrywka ${ }^{14}$ i 2) przedstawienie, widowisko,

13 Zob. szerzej: J. Fras, Dziennikarski warsztat językowy, Wrocław 1999.

$14 \mathrm{~W}$ ang. istotne jest rozróżnienie i podobieństwo pomiędzy amusement i entertainment. 
show (w tym także: news show) ${ }^{15}$. Ponadto entertainment tworzy w angielszczyźnie bogate pole słowotwórcze (entertain, entertainer, entertaining, entertainingly, entertainment industry, tribune entertainment, live entertainment), którego to kontekstu brakuje przejętemu terminowi w polszczyźnie.

Warto wreszcie zwrócić uwagę na jeszcze jeden istotny czynnik kontekstowy: niewątpliwie mamy dziś do czynienia z narzucaną przez piśmiennictwo anglosaskie tendencją do tworzenia hybrydowych terminów w medioznawstwie, a nawet szerzej - w naukach społecznych. Bez trudu można już bowiem przytoczyć kilkanaście, upowszechnianych także w polskim piśmiennictwie naukowym, terminów, zbudowanych na podobnej co infotainment zasadzie.

Tabela 1

Angielskie terminy hybrydowe z zakresu medioznawstwa

\begin{tabular}{||l|l|l||}
\hline \multicolumn{1}{|c|}{ Termin ang. } & \multicolumn{1}{c|}{ Slowa skladowe } & \multicolumn{1}{c|}{ Termin w polszczyźnie } \\
\hline mediamorphosis & media + metamorphosis & mediamorfoza \\
\hline journalmorphosis & journalism + metamorphosis & \\
\hline glocalisation & global + local & glokalizacja \\
\hline mediocracy (2001, T. Mayer) & mass media + democracy & mediokracja \\
\hline infomercial & infotainment + commercial & infomercial \\
\hline travelbrity & travel + celebrity & trawelebryta \\
\hline celeWEBrity & WWW + celebrity & celeWEBryta \\
\hline edutainment & education + entertainment & edutainment \\
\hline $\begin{array}{l}\text { politainment, politicotainment, } \\
\text { depolitainment }\end{array}$ & politics + entertainment & $\begin{array}{l}\text { politainment, politicotainment, } \\
\text { depolitainment }\end{array}$ \\
\hline snaparazzi & snapshot + paparazzi & snaparazzi \\
\hline
\end{tabular}

W najnowszych polskich publikacjach poświęconych rozrywkowym aspektom komunikacji politycznej pojawiły się dwa, bliskie tu rozważanemu terminy: politorozrywka i politicotainment. Wprowadzający je badacze tak różnicują znaczenia:

15 Zatem świadomość widowiskowości serwisów telewizyjnych jest językowo zakorzeniona; zob. A. Boyd, Dziennikarstwo radiowo-telewizyjne. Techniki tworzenia programów informacyjnych, Kraków 2006. 
- politorozrywka - ,jest kolejnym, po inforozrywce, stadium intruzji rozrywki w dziedziny życia publicznego" ${ }^{\text {"16; }}$

- politicotainment - ,reprezentacja i negocjowanie polityki w gatunkach rozrywkowych doczekało się określenia politicotainment. Ta nowa kategoria [-] denotuje sposoby, w jakie polityka i życie polityczne są interpretowane, negocjowane i reprezentowane przez przemysł rozrywkowy, a szczególnie przez seriale dramatyczne i telewizyjne programy bazujące na prawdziwych wydarzeniach" (Riegert 2007:1). "Innymi słowy, łączy ona politykę i rozrywkę, ale odmiennie niż infotainment”. W przypisie wyjaśniono, że: „Infotainment dotyczy przyjmowania funkcji rozrywkowej przez programy informacyjne i konotuje negatywną ocenę tego zjawiska" "17.

Tę swoistą serię słowotwórczą uzupełnił Z. Bauer: „Rola dziennikarstwa poważnego, analitycznego, publicznego poważnego dyskursu o poważnych sprawach stopniowo maleje, zostaje zmarginalizowana.

Życie społeczne - od polityki, poprzez ekonomię, sport i kulturę - traktowane jest jak spektakl tworzony przez media, dla mediów i następnie przez media relacjonowany. Zjawisko to określane niekiedy jako politainment, w gruncie rzeczy należy nazwać depolitainment, »spektaklem depolityzacji», którego efektem jest zniechęcenie odbiorców do aktywności publicznej"18. Wydaje się, że celem Bauera była jedynie swoista gra ze słowem politainment, a nie wprowadzenie nowego termi$\mathrm{nu}$ - spektakl depolityzacji jest tu bowiem, jako nazwa zjawiska, wystarczający i bardziej zgodny z polskimi zwyczajami językowymi.

Warto zastanowić się nad nieodzownością wprowadzenia dwu pierwszych terminów. Wedle przywołanych wyżej definicji politainment ma szersze znaczenie; politicotainment byłby terminem o węższym zakresie użycia, bo odnoszącym się jedynie do prymarnie rozrywkowych przekazów, do których włącza się (strywializowane) treści polityczne. Czy jednak polskie opisowe wyrażenia (nadmierna) rozrywkowość wypowiedzi politycznych i upolitycznione wypowiedzi rozrywkowe nie są wystarczające na określenie badanych zjawisk?

16 T. Olczyk, Politorozrywka i popperswazja, WAiP, Warszawa 2009, s. 87.

17 D. Piontek, Komunikowanie polityczne i kultura popularna. Tabloidyzacja informacji o polityce, Poznań 2011, s. 137.

18 Z. Bauer, Twój głos w Twoim domu: cztery typy tabloidyzacji, w: Tabloidyzacja języka i kultury, red. I. Kamińska-Szmaj, T. Piekot, M. Poprawa, „Oblicza komunikacji” 2010, nr 3, Wrocław 2010, s. 39. 


\section{Użycia terminu infotainment $\mathrm{w}$ wypowiedziach naukowych}

Analiza dotychczasowych użyć w tekstach naukowych i publicystycznych, wynika, że termin infotainment, prócz określania zawartości MM (jej treści i typow wypowiedzi), służy także charakteryzowania instytucji medialnych oraz tworców medialnych przekazów, czyli mediów i dziennikarstwa.

Tabela 2

Pojęcia określające infotainment w publikacjach naukowych i popularnonaukowych

\begin{tabular}{|c|c|c|c|}
\hline Ogólne & $\begin{array}{c}\text { Odnoszące się do } \\
\text { zawartości MM } \\
\text { (styl/sposób konstruo- } \\
\text { wania i prezentacji } \\
\text { zawartości) }\end{array}$ & $\begin{array}{c}\text { Odnoszące się do typu } \\
\text { wypowiedzi w MM } \\
\text { (kategoria genolo- } \\
\text { giczna) }\end{array}$ & $\begin{array}{c}\text { Odnoszące się do } \\
\text { swoistości MM (jako } \\
\text { instytucji) i dzienni- } \\
\text { karstwa }\end{array}$ \\
\hline $\begin{array}{l}\text { - zjawisko, } \\
\text { - pojęcie, } \\
\text { - kategoria, } \\
\text { - fenomen }\end{array}$ & $\begin{array}{l}\text { - formuła konstruowania } \\
\text { przekazów w MM, } \\
\text { - cecha/przejaw tabloidy- } \\
\text { zacji, } \\
\text { - cecha zawartości MM, } \\
\text { - element zawartości MM, } \\
\text { - formuła programowa } \\
\text { telewizji, } \\
\text { - przekaz medialny o okre- } \\
\text { ślonych cechach }\end{array}$ & $\begin{array}{l}\text { - nowy gatunek (hybry- } \\
\text { dowy), } \\
\text { - gatunek telewizyjny, } \\
\text { - przekaz o określonych } \\
\text { cechach, } \\
\text { - cecha gatunku wiado- } \\
\text { mość, } \\
\text { - megagatunek, } \\
\text { - pole gatunkowe obejmu- } \\
\text { jące wiele gat. hybrydo- } \\
\text { wych }\end{array}$ & $\begin{array}{l}\text { - trend, epoka w rozwoju } \\
\text { MM, } \\
\text { - przemysł rozrywkowy, } \\
\text { - nowa forma dziennikar- } \\
\text { stwa }\end{array}$ \\
\hline
\end{tabular}

Najczęściej infotainment pojmuje się jako formułę stylową i przypisuje się ją zwłaszcza serwisom informacyjnym ${ }^{19}$ lub pojedynczym wiadomościom. Serwisy informacyjne to jedyny typ wypowiedzi telewizyjnej o wielkiej, choć malejącej, oglądalności, niesprzedawany globalnie jako tzw. format ${ }^{20}$. Tu kolejne uściślenie terminologiczne: warto byłoby w medioznawstwie (a z pewnością przynajmniej w genologii) posługiwać się terminem format jedynie na określenie tych typów wypowiedzi

19 Zob. G. Ritzer, Makdonaldyzacja spoteczeństwa, Muza, Warszawa 1999, s. 219.

${ }^{20}$ Pojęcie format wywodzi się z podejścia producenckiego do jednostek zawartości MM; zob. A. Berger, Popular Culture Genres, Newbury Park, Sage Publications 1992; D. Bodycombe, How to devise a game show, Labyrinth Games, London 2003; I. Cury, Direction and Producing for Television: A Format Approach, Focal Press, Boston-Oxford-Auckland 2002. 
medialnych, które podlegają sprzedaży i licencjonowaniu, a zatem nie używać tego słowa jako synonimu gatunku wypowiedzi. Współcześnie wszystkie przekazy telewizyjne o wielkiej publiczności są już produkowane, sprzedawane i kupowane jako formaty, ale formaty nie są tożsame z gatunkami wypowiedzi. Najdłużej formatowaniu podlegają teleturnieje (od lat 60. XX w.); formatami są także w większości emitowane dziś $\mathrm{w}$ polskich stacjach telewizyjnych popularne seriale telewizyjne, talk shows oraz reality shows z licznymi mutacjami (ostatnio popularnością cieszą się formatowane talent shows).

Serwisy informacyjne, choć nie należą do formatów telewizyjnych, podlegają procesowi upodabniania się w wymiarze kontynentu czy już raczej globu - właśnie głównie ze względu na rosnącą rozrywkowość. To jeden $\mathrm{z}$ istotnych przejawów konwergencji zawartości $\mathrm{MM}^{21}$. Już N. Postman, pisząc o rozrywce jako nadideologii współczesnego dyskursu medialnego, wskazał następujące główne przejawy rozrywkowości serwisów informacyjnych:

- dobry wygląd i miły sposób bycia prezenterów (zazwyczaj są to gwiazdy mediów), którzy czarują urodą i wdziękiem; jeśli serwis prowadzi para - ich sympatyczne wzajemne przekomarzanie się;

- podniecający podkład muzyczny, który otwiera i zamyka widowiska informacyjne;

- żywy materiał filmowy, od atrakcyjnych reklam, towarzyszących serwisom począwszy ${ }^{22}$.

Należy dodać jeszcze atrakcyjność zawartości ikonicznej serwisów, dynamiczny montaż czołówki i newsów, świeżość/pierwszość/wyłączność publikacji wiadomości przez dany serwis (zwłaszcza tzw. big newsa), dominacja wiadomości niepoważnych/miękkich, przyjmowanie perspektywy zwykłego człowieka w przekazywaniu wiadomości poważnych, maksymalna personalizacja wiadomości (w warstwie ikonicznej i przyjęciu perspektywy prezentacji treści $)^{23}$.

21 M. Mrozowski, Telewizyjne programy informacyjne - polskie i zagraniczne (analiza porównawcza), „Studia Medioznawcze” 2009, nr 3 (38), s. 47; H. Jenkins, Kultura konwergencji. Zderzenie starych $i$ nowych mediów, Wyd. Akademickie i Profesjonalne, Warszawa 2007.

22 N. Postman, Zabawić się na śmierć: Dyskurs publiczny $w$ epoce show-businessu, wyd. polskie z 2002 r., s. 131. Emitowane zazwyczaj w czterech blokach reklamy przy polskich serwisach TV zajmują ok. 25 min., czyli co najmniej tyle samo czasu, co sam serwis.

23 Szerzej zanalizowała kwestię D. Piontek; medioznawczyni zwróciła też uwagę na sprofilowanie zawartości informacyjnej i rozrywkowej serwisów pod kątem 


\section{Infotainment w genologii dziennikarskiej i medialnej}

Niektórzy obserwatorzy ekspansji formuły nadmiernego urozrywkowienia wiadomości mówią nawet o powstaniu nowego gatunku dziennikarskiego, właśnie o nazwie - infotainment ${ }^{24}$, wypierającego jakoby ze zbioru gatunków medialnych gatunek wiadomość/news.

W świetle najnowszych ustaleń genologii dziennikarskiej i medialnej takie ujęcie jest błędne. Kluczowe dla uzasadnienia tej tezy jest rozumienie bazowego pojęcia gatunek. Gatunek, czyli wielokroć wykorzystywany typ wypowiedzi, należy uznawać za pojęcie abstrakcyjne, stosunkowo niezłożone/jednorodne, należące względnie trwale do podstawowego poziomu pojęciowego danej kultury ${ }^{25}$. Takie zinterpretowanie gatunku wypowiedzi wyklucza koncepty: gatunku hybrydowego czy gatunku mieszanego (którego przykładem miałby być infotainment). Można mówić jedynie o hybrydowości wypowiedzi, realizowanych w MM, czy o swoistej agregacji gatunków w popularnych wypowiedziach, o tendencji do tworzenia wypowiedzi hybrydowych (mieszanych) w MM w oparciu o wiele gatunków ${ }^{26}$.

W związku z powyższym nie ma podstaw do zmiany przekonania, że na poziomie abstrakcyjno-pojęciowym polskiej kultury pozostaje nadal

oczekiwań mężczyzn; zob. D. Piontek, Wiadomości jak dobranocka, „Gazeta Wyborcza" z 23-24 października 2010.

${ }^{24}$ Zob. np. W. Furman, A. Kaliszewski, K. Wolny-Zmorzyński, Gatunki dziennikarskie. Teoria - praktyka-jezyk, Wyd. Akademickie i Profesjonalne, Warszawa 2006. Autorzy zaliczają infotainment do małych gatunków informacyjnych w prasie (Ibidem, s. 34 i 39); z kolei K. Szymoniak pisze o dynamicznym rozwoju „tzw. inforozrywki, czyli infotainmentu, należącej do tzw. gatunków mieszanych”. Idem, Między gazetq a Internetem - nowe gatunki dziennikarskie, paragatunki czy hybrydy?, w: Język. Komunikacja. Informacja, red. P. Nowak, P. Nowakowski, t. 3, Poznań 2008. M. Palczewski uznaje z kolei infotainment za główny gatunek wypowiedzi informacyjnej we współczesnych mediach - Idem, Definicje i koncepcje newsa w tradycji anglosaskiej. Przeglad i próba klasyfikacji, „Studia Medioznawcze” 2009, nr 3 (38). Z kolei w Stowniku terminologii medialnej z 2006 r. podano, że zbiór gatunków infotainment nie obejmuje jednak wiadomości; zob. także przypis 2 .

${ }_{25}$ Zob. ostatnio J. Fras, Podstawy identyfikacji i typologii wypowiedzi w mediach masowych, w: Komunikologia - teoria i praktyka komunikacji, red. E. Kulczycki, M. Wendland, Wyd. Naukowe IF UAM, Poznań 2012.

${ }^{26}$ Można rozważyć przydatność terminu megawypowiedź czy nawet przyjąć termin megagatunek, ale tylko w odniesieniu do realizacji w MM na określenie typowych wielogatunkowych wypowiedzi, zrealizowanych w MM. 
jako wzorzec gatunkowy wiadomość (dziennikarska) - prymarnie informacyjna i nierozrywkowa. Istotę wzorcowej wiadomości (gatunku) można ująć, posługując się znaną formułą 5 pytań lub językiem semantycznym A. Wierzbickiej („Chcę, żebyś wiedział, że coś się wydarzyło”27).

Tak pojęta prototypowa wiadomość służy - nie tylko w MM - przekazywaniu aktualnych informacji o rzeczywistości i ta zawartość informacyjna jest kluczowa dla swoistości gatunkowej wiadomości/newsa. Także wzorcowo pojęty serwis wiadomości składa się z kilku/kilkunastu jednostek - wiadomości o funkcji informacyjnej. Nie ma więc podstaw do wyodrębniania nowego gatunku infotainment; tym bardziej do wyodrębniania pola gatunkowego czy megagatunku o tej nazwie ${ }^{28}$.

Dla mediów i dziennikarstwa nadal podstawowy jest więc wzorzec wiadomości prymarnie informacyjnej (w treści poważnej/istotnej), pozostaje on bowiem podstawowy w racjonalnej - mimo wszystko - międzyludzkiej komunikacji sensu largo. W większości obszarów życia publicznego, opartych na racjonalnym dyskursie, istotna poznawczo wiadomość jest głównym gatunkiem wypowiedzi (informacyjnym). To, że styl rozrywkowy dominuje w popularnych mediach, sprawiając, że publikowane $\mathrm{w}$ nich serwisy tracą walory informacyjne na rzecz rozrywkowych, nie zmienia ważnosci informacyjnego nurtu komunikacji i jej głównego gatunku - wiadomości. Zapewne konsekwencją urozrywkowienia popularnych serwisów będzie jakościowe ich zróżnicowanie: te zawierajace wiadomości z istotnymi informacjami będą elitarne i specjalistyczne, trudniej dostępne, trudniejsze w odbiorze, zapewne płatne; te popularne - łatwe i niepłatne, będą z kolei zdominowane przez miałkie treści informacyjne i rozrywkowe.

Warto też przypomnieć, że w połowie lat 90 . XX w. ukuto już termin newszak na określenie newsow łatwo przyswajalnych, zatem także głównie rozrywkowych, preferujących sprawy krajowe (z dominacją spraw kryminalnych, sensacyjnych, z udziałem celebrytów), przyjmujących

27 Za: T. Piekot, op. cit., s. 42.

28 Pole gatunkowe (generic field) infotainment wyodrębnia S. Stockwell, zaliczając doń liczne telewizyjne wypowiedzi hybrydowe: mockumentary, docusoup, docudrama, docugame, doculifestyle, life style show - zob. S. Stockwell, Reconsidering the Fourth Estate: The functions of infotainment, wystapienie podczas spotkania Australian Political Studies Association na Uniwersytecie w Adelajdzie (29 września-1 października 2004) dostępne w formie elektronicznej: http://www.adelaide.edu.au/apsa/docs_papers/Others/Stockwell.pdf (9.07.2012). 
perspektywę zwykłego człowieka ${ }^{29}$. Ponadto w 1988 r. J. Strömbäck wprowadził też określenie news tabloidowy (także: junk food news, pol. news tabloidowy) i ten termin także wystarczająco wskazuje istotę treści i stylu omawianych wiadomości ${ }^{30}$.

Wydaje się, że w empirycznych badaniach newsów i serwisów informacyjnych pod kątem ich rozrywkowości, wystarczy posługiwać się terminologią już utrwaloną, czyli określeniami: wiadomość poważna, twarda i niepoważna (miękka, tabloidowa). Dysponujemy już wynikami wielu badań telewizyjnych serwisów informacyjnych pod kątem ich urozrywkowienia, najwięcej w amerykańskich MM. Z szeroko spopularyzowanych badań zawartości amerykańskich serwisów telewizyjnych, przeprowadzonej przez T. Pattersona w końcu minionego wieku wynika, że 60\% ich czasu jest przeznaczone na wiadomości miękkie, niedotyczące polityki lub spraw ważkich z punktu widzenia interesu publicznego i że ten procent rośnie $\mathrm{z}$ roku na rok. Liczne już badania nad polskimi newsami i serwisami informacyjnymi np. T. Piekota (z lat 2000-2002) $)^{31}$, M. Mrozowskiego (z roku 2008) ${ }^{32}$, wreszcie D. Piontek (z lat 2009-2010) ${ }^{33}$ unaoczniaja podobną tendencję - w serwisach ubywa newsów poważnych, a przybywa tabloidowych. Istotne dla badań zawartości polskich serwisów informacyjnych jest połączenie dwu, najczęściej dotąd oddzielanych perspektyw - postrzegania newsów jako przekazów ideologiczno-perswazyjnych i jako przekazów rozrywkowych.

\section{Infotainment a tabloidyzacja}

Przede wszystkim należy wskazać, że obydwa określenia jako terminy naukowe są nienajlepsze, ze względu na swą negatywną konotację.

29 B. Franklin, Newszak and News Media, London 1997, za: M. Palczewski, Definicje $i$ koncepcje newsa $w$ tradycji anglosaskiej. Przeglad i próba klasyfikacji, „Studia Medioznawcze” 2009, nr 3 (38), s. 63.

30 J. Strömbäck, Four Phases of Mediatization: An Analyzis of Mediatization of Politics, „The International Journal of Press/Politics”, July 2008, vol. 13, no. 3, s. 228-246, 231.

31 Zob. więcej: T. Piekot, Dyskurs polskich wiadomości prasowych, TAiWPN Universitas Kraków, Kraków 2006.

32 M. Mrozowski, M. Mrozowski, Telewizyjne programy informacyjne - polskie i zagraniczne (analiza porównawcza), „Studia Medioznawcze” 2009, nr 3 (38).

${ }_{33}$ D. Piontek, Komunikowanie polityczne i kultura popularna. Tabloidyzacja informacji o polityce, Poznań 2011. 
Trudno też mówić o spełnianiu przez nie kryteriów precyzji i jednoznaczności: procesy i zjawiska, do których się odnoszą, są złożone (warto pamiętać o rozróżnieniu pomiędzy procesem tabloidyzacji i jego skutkami/przejawami ${ }^{34}$ ), zależne od wielu zmieniających się okoliczności, w tym od nowych technologii komunikacji.

W pracach medioznawczych tabloidyzacja wydaje się być już dobrze umocowaną koncepcją analityczną w nurcie krytycznym, służącą od dość dawna wyjaśnianiu relacji mediów masowych i społeczeństwa, umożliwiającą zrozumienie i analizę zwłaszcza instytucjonalnych przemian współczesnej polityki i demokracji oraz ukierunkowywanie badań empirycznych, np. analizy zawartości, KAD i języka tabloidowych mediów.

Kierując się regułą niemnożenia terminów naukowych ponad miarę, czyli pamiętając o brzytwie Ockhama, najlepiej byłoby zaniechać posługiwania się terminem infotainment $\mathrm{w}$ obu rozważonych powyżej znaczeniach (formuły stylowej i gatunku wypowiedzi). Tendencję do nadmiernej rozrywkowości zawartości MM można przecież uznać za przejaw tabloidyzacji w szerokim sensie ${ }^{35}$. Wedle F. Essera tabloidyzacja może być pojmowana jako mikroproces, wówczas istotny jest dobór tematów (więcej rozrywkowych mniej istotnie informacyjnych) i ich ujęcie (większość krótkich newsów, niewiele dłuższych i dobrze udokumentowanych; przewaga zdjęć i ilustracji) ${ }^{36}$ i w tym rozumieniu jest zbieżna $\mathrm{z}$ pojmowaniem infotainmentu.

$\mathrm{Z}$ pewnością infotainment $\mathrm{w}$ wąskim sensie - jako gatunek telewizyjny - należy uznać za termin zbędny, jeśli założyć, że gatunki są abstrakcyjnymi prototypami wypowiedzi, a w rejestrze prototypów naszej kultury mamy już wiadomość dziennikarską. Neologizm infotainment, podobnie jak wcześniejszy newszak, nazywają - mam nadzieję - przemijające twory „wiadomościopodobne” z poziomu realizacji w MM, a nie z abstrakcyjnego poziomu kultury, do którego należą także pojęcia generyczne.

Za przedwczesną uważam także diagnozę M. Palczewskiego: „Obecnie - pod wpływem procesów globalizacji, tabloidyzacji i internetyzacji

34 J. Fras, Tabloidyzacja a mediatyzacja i logika mediów - wzajemne relacje pojęć, w: Współczesne media. Wolne media?, red. I. Hofman, D. Kępa-Figura, t. II, Wyd. UMCS, Lublin 2010, s. 59-80.

35 Zob. J. Fras, op. cit.

36 F. Esser, Tabloidization of News. A Comparative Analyzis of Anglo-American and German Press Journalism, „European Journal of Communication” 1999, vol. 14, s. 293. 
- mamy do czynienia z nowym paradygmatem newsa, który w coraz większym stopniu przyjmuje formę lekkiej informacji połączonej z rozrywka, seksem i tzw. human stores" ${ }^{\prime 37}$.

Niewątpliwie na poziomie realizacji wypowiedzi we współczesnych, popularnych MM mamy do czynienia z nadmiernym podporządkowywaniem treści, formy i stylu wypowiedzi informacyjnych funkcji rozrywkowej, ale to nie oznacza zmiany fundamentalnej i nieodwracalnej. Stałego krytycznego oglądu warte są następujące tendencje we współczesnych MM: włączanie serwisów informacyjnych do głównego (rozrywkowego) nurtu zawartości MM oraz nasycanie dotąd poważnych i propagandowych serwisów łatwą rozrywką. Szczególnie warto zajmować się najgroźniejszym przejawem tabloidyzacji: łączeniem rozrywki i nieetycznej perswazji.

\section{Dziennikarstwo rozrywkowe}

Przede wszystkim warto zastanowić się, czy dostarczanie rozrywki publiczności MM należy do podstawowych celów pracy dziennikarzy? $\mathrm{Z}$ dotychczasowych ujęć, co prawda bardziej normatywnych niż opisowych, wynika, że nie. W żadnej ze znanych typologii zawodu dziennikarskiego dziennikarstwo rozrywkowe nie jest bowiem wyodrębniane. Badacze piszą co najwyżej o dziennikarstwie marketingowym ${ }^{38}$, nastawionym na zaspokajanie oczekiwań publiczności, co „może oznaczać dryfowanie w kierunku czystej komercji i oferowanie publikacji przygotowanych najmniejszym kosztem"39.

Niewątpliwie, rozwój medialnego przemysłu rozrywkowego łączy się z zapotrzebowaniem na nowe zawody i specjalności, których lepiej nie uznawać za stricte dziennikarskie, a raczej medialne i związane głównie z rozrywką telewizyjną. Popularni prezenterzy telewizyjni serwisów informacyjnych, gospodarze popularnych talk show czy pro-

37 M. Palczewski, Definicje i koncepcje newsa w tradycji anglosaskiej. Przeglad i próba klasyfikacji, „Studia Medioznawcze” 2009, nr 3 (38).

38 S. Michalczyk, Społeczeństwo medialne. Studia z teorii komunikowania masowego, Katowice 2008, s. 129, za: V. Wyssem oraz K. Wolny-Zmorzyński, A. Kaliszewski, W. Furman, Gatunki dziennikarskie, WAiP, Kraków 2006, s. 147, za H. Puererem.

39 Ibidem, s. 47. 
wadzący wywiady z politykami nie muszą być dziennikarzami. Choć dziennikarz w Polsce raczej nie posłuży się samoidentyfikacją: „Jestem dziennikarzem rozrywkowym", środowisko dziennikarskie akceptuje coraz bardziej wymogi przemysłu rozrywkowego. Dziennikarz, który zdobył popularność w serwisie informacyjnym czy ambitniejszej publicystyce, może udzielać się równocześnie w widowiskach rozrywkowych (np. J. Kuźniar prowadzi w TVN serwis Fakty i talent show X Factor), a nawet występować w kampaniach reklamowych (np. W. Mann). Znamienne, że nie przejęliśmy do polszczyzny ang. entertainer („zabawiacz"); choć showman zastąpił artystę estradowego. Publicyści tworzą też hybrydowe neologizmy, mające oddać specyfikę nowych zawodów, np. K. Lubelska w „Polityce” określiła K. Wojewódzkiego predaktorem $(\text { prezenter }+ \text { redaktor })^{40}$.

Krytyczni obserwatorzy MM kwestionują przynależność ,zabawiaczy" i showmenów do grona dziennikarzy. Wskazują też na destrukcyjne poczynania właścicieli MM: ,Już od dawna telewizja przyczynia się do rozmycia zarówno samych wartości, jak i wizerunku dziennikarstwa [...] zanika różnica między dziennikarzem wykształconym, ciężko pracującym np. jako reporter z miejsc szczególnie niebezpiecznych, np. z Somalii czy Ruandy, a »zabawiaczem« Karlem Zero, prezenterem telewizyjnym [...] podającym sensacyjne i niesprawdzone »informacje«, łączącym karykaturę dziennikarstwa $\mathrm{z}$ tanią rozrywką.

Jaki jest związek między piękną młodą blondynką, która z uśmiechem odczytuje z promptera tekst, najczęściej zredagowany przez kogoś innego (przez długi czas CNN zatrudniało do czytania wiadomości aktorów, grających dziennikarzy) a dziennikarzem potrafiącym w przejrzysty sposób wyjaśnić skomplikowane kwestie, związane z budżetem państwa? Jaki jest związek pomiędzy marnie opłacanym stażystą, kompilującym informacje ze strony internetowej, a reporterem, działającym w terenie?" $"$.

Wzrostowi znaczenia w MM specjalności zawodowych związanych z przemysłem rozrywkowym sprzyja zacieranie granic pomiędzy sferą wytwarzania zawartości tychże mediów a marketingiem i komunikacją

40 Zob. także więcej o zawodach medialnych: W. Godzic, Prezenter, ekspert, celebrity, w: Media audiowizualne. Podręcznik akademicki, red. W. Godzic, WAiP, Warszawa, s. 299-323.

41 B. Poulet, Śmierć gazet i przyszłość informacji, Wydawnictwo Czarne, Sękowa 2011 , s. 88 . 
PR, coraz istotniej wpływającymi na funkcjonowanie współczesnych komercyjnych MM.

\section{Nadmierne urozrywkowienie dyskursu medialnego - refleksja teoretyczna i główne nurty badawcze}

Co najmniej od połowy minionego wieku filozofowie społeczni, socjologowie i medioznawcy śledzą z niepokojem nieoświeceniową rolę popularnych MM, negatywnie oceniając zwłaszcza czynienie przez nie z treści politycznych i kulturalnych łatwo dostępnego, doraźnie atrakcyjnego towaru, co skutkuje m.in. jałowieniem kultury politycznej (zarówno polityków, jak i wyborców).

Procesy te, dziś określane głównie mianem nadmiernej medializacji lub tabloidyzacji współczesnego życia społecznego, łączy się ze wzrostem komercjalizacji doświadczeń przyjemności, relaksu i rozrywki w czasie wolnym, czerpanych z użytkowania zawartości MM, a głównie - cyklicznych i sformatowanych widowisk telewizyjnych. Badania demoskopijne publiczności MM wykazują rekordy oglądalności właśnie widowisk sportowych, popularnych telewizyjnych seriali, talk shows, reality shows, a ostatnio talent shows.

Krytyczni badacze kultury i MM piszą o szczególnym znaczeniu rozrywki medialnej dla współczesnych społeczeństw cywilizacji zachodniej. Najbardziej znana jest diagnoza amerykańskiego filozofa i medioznawcy N. Postmana, który w 1985 r. określił rozrywkę: „,...] nadideologią całego dyskursu w telewizji. Niezależnie od tego co i z jakiego punktu widzenia jest przedstawiane, to zgodnie z przyjętym z góry założeniem - ma służyć naszemu rozbawieniu i przyjemności"42.

Zaakceptowanie tej nadideologii przez użytkowników, zwłaszcza audiowizualnych mediów łączy się z następującymi korzyściami i przyjemnościami:

- eskapizm/ucieczka od rzeczywistości,

- stymulacja do określonych, przyjemnych zachowań (głównie do konsumpcji),

- identyfikowanie (się)/naśladowanie/bliskość/możliwość szybkiej, także negatywnej, oceny głównych postaci przekazów,

42 N. Postman, Zabawić się na śmierć: Dyskurs publiczny w epoce show-businessu, Wyd. Muza, Warszawa 2002, s. 120-131. 
- doświadczenie pochlebstwa i pobłażania niewiedzy,

- zadowolenie, a nawet entuzjazm, związany z przeświadczeniem o podzielaniu tych stanów przez innych (ostatnio w mediach społecznościowych),

- zadziwienie, szok etc., wywoływane okazywanymi odstępstwami od norm etycznych, estetycznych itd.,

- ambiwalencja doznań i uczuć, choć zasadniczo głównie desensystyzacja,

- uzależnienie od spędzania czasu na użytkowaniu MM.

Jeśli więc ludyczność i konsumpcja tak silnie oddziałują na współczesną kulturę, a znaczenie przyjemności czerpanych z MM współcześnie jest tak wielkie, nadmierna rozrywkowość popularnych serwisów informacyjnych, wzorem innych, popularnych przekazów medialnych, jest nieunikniona. Warto rozróżnić dwa, obserwowane już od lat 70. XX w., nurty tego ważnego przejawu konwergencji zawartości MM:

1) silniejszy - intruzja rozrywkowych treści i zachowań dziennikarzy do poważnych przekazów i mediów np. do serwisów informacyjnych;

2) słabszy - włączanie treści poważnych (np. politycznych) do przekazów i mediów prymarnie jedynie rozrywkowych bądź niższej intelektualnej i poznawczej jakości, np. pojawienie się reklam politycznych i społecznych, politycznych talk shows czy seriali z wątkami politycznymi.

W polskim medioznawstwie i komunikologii badania nad aspektem rozrywkowym zawartości mediów i dziennikarstwa są dopiero inicjowane; korzystamy więc głównie $\mathrm{z}$ dorobku medioznawstwa zachodniego. Bodaj pierwszy o roli rozrywki w MM, uwzględniając szeroko krytyczne podejście, pisał M. Mrozowski w znanym i cenionym podręczniku akademickim Władza, rozrywka $i$ biznes ${ }^{43}$. Możliwości prowadzenia szerszych badań empirycznych nad wypowiedziami telewizyjnymi powstały w Polsce dopiero od dwudziestu lat; badania nad rozrywkowym aspektem polskich serwisów informacyjnych zainicjowano dopiero $\mathrm{w}$ ostatnim dziesięcioleciu.

W dotychczasowej refleksji naukowej nad rozrywkowością MM i ich zawartości warto wskazać trzy główne nurty: funkcjonalny, historyczny i krytyczno-dyskursywny. Funkcja rozrywkowa MM została wyodrębniona na podstawie obserwacji amerykańskich MM już w $1960 \mathrm{r}^{44}$, choć

43 M. Mrozowski, Media Masowe. Władza, rozrywka i biznes, Warszawa 2001.

44 Ch. R. Wright, Mass Communication, New York 1975, s. 12-14. 
nigdy nie została uznana przez medioznawców za główną funkcję MM. W najbardziej dziś spopularyzowanej typologii D. McQuaila funkcja rozrywkowa ustępuje informacyjnej, korelacyjnej i ciągłości, a poprzedza mobilizacyjną ${ }^{45}$.

Rozrywka medialna jest także pojmowana jako efekt oddziaływania mediów (media effect) lub ich wpływ (media influence) ${ }^{46}$. Współcześnie, gdy produkcja rozrywki na potrzeby MM to istotny segment nowoczesnej gospodarki ${ }^{47}$, nikt $\mathrm{z}$ badaczy nie ma jednak wątpliwości co do szczególnej roli MM w kreowaniu, realizowaniu i zaspokajaniu zapotrzebowania na rozrywkę. Znaczenia rozrywki nie mogą nie dostrzegać media publiczne, które także w Polsce poszerzają swoją ofertę o kanały stricte rozrywkowe: TVP w marcu 2012 r. wystapiła do KRRiT o koncesje na dwa kanały tematyczne: właśnie rozrywkowy i dokumentalny ${ }^{48}$.

W podejściu historycznym do rozrywkowości MM warto zwrócić uwage na holistyczne rozważania o rozwoju komunikacji I. Fanga z $1997 \mathrm{r}^{49} \mathrm{~W}$ jego ujęciu rewolucja rozrywkowa była jedną z sześciu wielkich rewolucji w historii komunikacji. Stanowi bowiem czwartą istotną zmianę w rozwoju komunikacji; po rewolucjach: pisma (w VIII w. w Grecji); druku (w 2 poł. XV w. w Europie) i masowych mediów (w poł. XIX w., Europa Zachodnia i wsch. część USA). Rewolucja rozrywkowa została zainicjowana w końcu XIX w. w Europie zachodniej, $\mathrm{w}$ związku z pojawieniem się przemysłu rozrywkowego, opartego na upowszechnieniu aparatu fotograficznego, filmu, fonografii i tabloidow. Następne rewolucje wzmacniają znaczenie rozrywkowości MM, są to bowiem: udomowienie sprzętu medialnego w połowie XX w. i pojawienie się najnowszych mediów w końcu XX w., aktualnie uzupełnianych o media społecznościowe, których I. Fang jeszcze w swych rozważaniach nie uwzględniat.

Największy bodaj wkład do refleksji nad społeczno-kulturowymi aspektami rozrywkowości MM mają badacze ze szkoły krytycznej, z nurtu

45 D. McQuail, Mass Communication Theory, Sage 2005, s. 79-80.

46 D. Zillman, L. Bryant, Entertainment as media effect, w: Reader in Mss Communication Theory, red. D. McQuail, London-Thousand Oaks-New Delhi 2003, s. 406.

47 Zob. Entertainment and Media Statistics - Plunkett Research, www.plunkettresearch.com.

${ }^{48} \mathrm{~W}$ ten ostatni ma się przekształcić kanał Historia. TVP miała już raz koncesję na kanał rozrywkowy, ale cofniętą w 2008 r. przez KRRiT.

49 I. Fang, A History of Mass Communication. Six Information Revolutions, Boston 1997 , s. XV. 
KAD i badań kulturowych. Podstawowym założeniem w podejściu krytycznym jest, najogólniej określając, przekonanie, że MM współprzynależą do szerszej struktury społeczno-kulturowej, którą wyznaczają i determinują stosunki władzy w społeczeństwie (główni przedstawiciele nurtu krytycznego: T. Adorno, M. Horkhaimer, A. Gramsci, B. R. Barber, N. Postman, E. S. Herman i N. Chomsky, G. Debord, P. Dahlgren, J. Baudrillard, G. Murdock i in.).

Także w KAD zakłada się, że właściciele MM (czy szerzej środków produkcji kultury) oraz tworcy publikowanych w nich przekazów mają większy wpływ na treści przekazów (ich aspekt znakowy, konotacyjny i mityczny), niż odbiorcy przekazów, czy jak dziś mówimy - ich użytkownicy. Choć, oczywiście, ci ostatni uczestniczą w kreowaniu ogólnego sensu przekazów (na trzy sposoby - wedle znanego ujęcia S. Halla), to zawsze ulegają władzy symbolicznej i ukierunkowywaniu socjalizacji przez MM, które uzupełniają a często zastępują inne instytucje (rodzinę i system wychowaczy, kościoł, szkolnictwo, partie polityczne, instytucje kultury). MM są zawsze uwikłane w system ekonomiczny i polityczny, muszą być zatem swoistym pasem transmisyjnym dominującej grupy społecznej lub wręcz narzędziem hegemonii tej grupy. Także w systemach tzw. wolnych mediów wolność kreowania zawartości MM jest zatem iluzoryczna.

Hegemonia grupy dominującej w danej wspólnocie komunikacyjnej polega na (dobrowolnym) zaakceptowaniu przez inne grupy zasadniczych przesłanek organizujących wspólnotę: przede wszystkim to zgoda na tę dominację oraz związane $\mathrm{z}$ nią idee, wartości moralne i śwatopoglądowe. MM utwierdzają grupy podporządkowane w przekonaniu, że wyrażają naturalny, normalny porządek rzeczy ${ }^{50}$. Rozrywkowość, widowiskowość i emocjonalizacja przekazów medialnych sprzyjają dobrowolności zgody grup podporządkowanych na hegemonię elit oraz akceptacji przez nie powyższych relacji, idei i wartości. Istotne jest też, że rozrywka w MM uzależnia - jako atrakcyjniejsza od codziennej rzeczywistości i rozrywki realnej, aranżowanej poza mediami. O znaczeniu uzależnienia od MM pisał sugestywnie N. Postman - to co poza mediami staje się nudne i puste, bo superbodźce płynące z ekranu znacznie przewyższają

50 M. Mrozowski, Media Masowe. Władza, rozrywka i biznes, Warszawa 2001, s. 221. 
atrakcyjnością te z „szarej rzeczywistości”; dysfunkcję uzależnienia od MM wskazali już w 1948 r. K. Lazarsfeld i R. K. Merton.

Krytyczną interpretację działania MM, głównie telewizji, stworzył także G. Gerbner w teorii kultywowania głównego nurtu kultury przez $\mathrm{MM}^{51}$. Kultywowanie to oznacza stopniowe kształtowanie i umacnianie przekonań odbiorców o świecie zewnętrznym, zgodnych z tym kreowanym w MM (stereotypowym, zniekształconym, wybiórczym). Analiza G. Gerbnera opierała się na trzech założeniach:

- telewizja jest centralnym medium codziennosci (główne miejsca siedzące w pokoju dziennym są zorientowane na odbiornik telewizyjny, jeszcze na początku XX w. były zorientowane na stół $)^{52}$,

- konstrukcja świata wirtualnego (w telewizji) jest dokonywana na użytek dominującej grupy społecznej i świata biznesu; służy utrzymaniu konwencjonalnych przekonań, zachowań oraz hierarchii społecznej, - odbiór telewizji to czynność głównie rytualna, audytorium nie jest skupione na odbiorze, a uwaga użytkowników MM jest zawsze selektywna.

W MM komercyjnych, zazwyczaj skierowanych „,do warstw gorzej wykształconych, zasadą polityki informacyjnej jest zaangażowanie w problemy »zwyczajnych ludzi«, tzn. zajmujących niską pozycję w społeczeństwie, słabo pojmujących zasady jego działania i tylko częściowo je akceptujących"53. Z tego względu popularne MM komercyjne muszą być populistyczne i antyelitarne; np. w wyjaśnianiu wad i mankamentów złożonej rzeczywistości politycznej muszą posługiwać się upraszczającą personalizacją (to ludzkie, potocznie zrozumiałe, ułomności członków elit je powodują).

MM uczestniczą w obu głównych technikach osiagania dominacji przez elity: w produkowaniu dyskursu i produkowaniu mitów, w tym metamitu $^{54}$ (czy jak pisze N. Postman, nadideologii), rozrywki we współczesnej kulturze, zdominowanej przez zmedializowaną kulturę masową.

51 G. Gerbner, L. Gross, M. Morgan, N. Signorielli, Living with television: The dynamics of the cultivation process, w: Perspectives on media effects, Hilldale, red. J. Bryant, D. Zillman, Lawrence Erlbaum Associates, New York 1986, s. 17-40.

${ }^{52} \mathrm{~W}$ Polsce takie badania przeprowadził M. Halawa - Idem, Życie codzienne z telewizorem. Z badań terenowych, WAiP, Warszawa 2006.

53 M. Mrozowski, op. cit., s. 252.

54 W komunikologii przyjmuje się najczęściej Barthesowskie ujęcie mitu: to kulturowo utrwalony sposób konceptualizowania, rozumienia i myślenia/mówienia o czymś. Mity są systemami semiologicznymi nabudowanymi na znaki i ich konotacje; U. Eco, Nieobecna struktura, Wyd. Aletheia, Warszawa 2003. 


\section{Zakończenie}

Co do istoty zjawiska, które najlepiej określić opisowo - nadmierną rozrywkowością zawartości MM (zwłaszcza serwisów informacyjnych), a krócej tabloidowością MM - jego zrozumieniu i przedsięwzięciu działań zaradczych najbardziej potrzebna jest krytyczna refleksja środowisk najbardziej „uwikłanych”, czyli dziennikarzy, zwłaszcza dziennikarzy informacyjnych (politycznych, ekonomicznych) oraz właścicieli MM. $\mathrm{Z}$ pewnością nie na wiele się zdadzą spektakularne protesty indywidualne, jak choćby ten amerykańskiej dziennikarki Miki Brzezinski, która 26.06.2007 r. w porannym programie informacyjnym stacji MSNBC, w proteście przeciw emisji wiadomości o wyjściu z więzienia P. Hilton, przeprosiła telewidzów („Muszę was przeprosić za pierwszy materiał. Nie ja go wybrałam") i zaaranżowała widowiskowy happening - podpaliła na wizji skrypt z wiadomością.

Jeśli taki konstruktywny namysł środowisk medialnych nad zanikiem poznawczych i oświeceniowych walorów serwisów informacyjnych mają wspomagać badacze mediów to z pewnością winni dbać szczególnie o jasność i adekwatność używanych pojęć i terminów. Ukucie i upowszechnienie terminu infotainment, jak zresztą wielu podobnych (zob. tab. 1), związanych z komunikacją medialną i jej problemami, stanowi przejaw pewnej mody na terminy hybrydowe, zainicjowanej w medioznawstwie angloamerykańskim. Jednakże, jak wykazano powyżej, walory eksplanacyjne takiego, przejętego bez kontekstu pojęciowo-kulturowego, terminu są nikłe; hybrydowa nazwa obca tak wieloaspektowego zjawiska nie ułatwia jego zrozumienia, a ze względu na szeroki zakres użycia (przejaw konwergencji, formuła stylowa, nazwa gatunkowa) bardzo utrudnia debatę naukową.

W jakościowej analizie polskiego dyskursu medialnego najlepiej byłoby mówić o tabloidowości mediów i dziennikarstwa lub posługiwać się polskimi wyrażeniami np. wzrost znaczenia popularnych wypowiedzi rozrywkowych, wzrost znaczenia treści rozrywkowych w przekazach informacyjnych (w serwisach informacyjnych), wzrost znaczenia mediów rozrywkowych i dziennikarstwa rozrywkowego.

\section{Bibliografia}

Demers D., Dictionary of Mass Communication and Media research: a guide for students, scholars and professionals, Marguette 2005. 
Esser F., Tabloidization of News. A Comparative Analysis of Anglo-American and German Press Journalism, „European Journal of Communication” 1999, vol. 14, s. $291-324$.

Fang I., A History of Mass Communication. Six Information Revolution, Boston 1997.

Fras J., Dziennikarski warsztat językowy, Wrocław 1999.

Fras J., Podstawy identyfikacji i typologii wypowiedzi w mediach masowych, w: Komunikologia - teoria i praktyka komunikacji, red. E. Kulczycki, M. Wendland (red.), Wyd. Naukowe IF UAM, Poznań 2012.

Fras J., Tabloidyzacja a mediatyzacja i logika mediów - wzajemne relacje pojęć, w: Współczesne media. Wolne media?, red. I. Hofman, D. Kępa-Figura, t. II, Wyd. UMCS, Lublin 2010, s. 59-80.

Godzic W., Prezenter, ekspert, celebrity, w: Media audiowizualne. Podręcznik akademicki, red. W. Godzic, WAiP, Warszawa.

Goban-Klas T., Cywilizacja medialna. Geneza, ewolucja, eksplozja, WSiP, Warszawa 2005.

Halawa M., Życie codzienne z telewizorem. Z badań terenowych, WAiP, Warszawa 2006.

Holtz-Bacha C., Political communication research abroad Europe, w: Handbook of Political Communication Research, red. L. L. Kaid, Lawrence Erlbaum Associates, Mahwall 2004, s. 463-477.

Tabloidyzacja języka i kultury, red. I. Kamińska-Szmaj, T. Piekot, M. Poprawa, „Oblicza komunikacji” 2010, nr 3, Wrocław 2010.

Krzemiński A., Mediokracja, „Polityka” z 16.04.2011.

Mrozowski M., Media Masowe. Władza, rozrywka i biznes, Warszawa 2001.

McQuail D., Mass Communication Theory, Sage 2005.

Narodowy Korpus Języka Polskiego, www.nkjp.pl.

Olczyk T., Politorozrywka i popperswazja, WAiP, Warszawa 2009.

Palczewski M., Definicje i koncepcje newsa w tradycji anglosaskiej. Przeglą i próba klasyfikacji, „Studia Medioznawcze” 2009, nr 3 (38).

Piontek D., Komunikowanie polityczne i kultura popularna. Tabloidyzacja informacji o polityce, Poznań 2011.

Piontek D., Wiadomości jak dobranocka, „Gazeta Wyborcza” z 23-24.10.2010.

Poulet B., Śmierć gazet i przyszłość informacji, Wydawnictwo Czarne, 2011.

Postman N., Zabawić się na śmierć: Dyskurs publiczny w epoce show-businessu, Wyd. Muza, Warszawa 2002.

Stockwell S., Reconsidering the Fourth Estate: The functions of infotainment, wystapienie podczas spotkania Australian Political Studies Association na Uniwersytecie w Adelajdzie (29 września-1 października 2004) dostępne w formie elektronicznej: http:/www.adelaide.edu.au/apsa/docs_papers/Others/Stockwell.pdf (9.07.2012). 
Strömbäck J., Four Phases of Mediatization: An Analyzis of Mediatization of Politics, „The International Journal of Press/Politics”, July 2008, vol. 13, no. 3, s. $228-246$.

Szymoniak K., Między gazetq a Internetem - nowe gatunki dziennikarskie, paragatunki czy hybrydy?, „Język. Komunikacja. Informacja”, red. P. Nowak, P. Nowakowski, nr 3/2008, s. 121-138.

Worsowicz M., Inforozrywka w prasie, w: Nowe media, nowe w mediach, red. I. Borkowski, A. Woźny, Wyd. Uniwersytetu Wrocławskiego, Wrocław 2001.

Wright Ch. R., Mass Communication, New York 1975.

Zillmann D., Bryant J., Entertainment as media effect, w: Reader in Mass Communication Theory, red. D. McQuail, London-Thousand Oaks-New Delhi 2003.

Żórawski K., Wirus wiecznej zabawy, „Gazeta Wyborcza” z 9.02.2009.

\title{
On the understanding of infotainment in modern media studies and the excessive focus on entertainment in the mass media
}

\begin{abstract}
Summary
The excessive focus on entertainment in the content of the modern mass media has become the subject of academic reflection in Poland over the last decade. In the West this issue has been discussed for at least thirty years. Out of the various concepts that serve the purpose of describing and analyzing the focus on entertainment in the mass media the author focuses on the concept of infotainment, borrowed from American English; the meaning and scope of this concept in academic and journalistic texts is analyzed. It is indicated that the concept has a limited explanatory value when taken over without its cultural and linguistic context, and it is particularly useless as the name of a genre, used instead of the news.

Discussing contemporary academic reflections on the focus on entertainment in the mass media and their content, three main currents are indicated and briefly described: the functional, historical and critically-discursive; the issue of the focus on entertainment of professional journalists is also addressed.
\end{abstract}


